\title{
PENGARUH PENDEKATAN SETS (SCIENCE, ENVIRONMENT, TECHNOLOGY AND SOCIETY TERHADAP KETERAMPILAN PROSES SAINS SISWA SEKOLAH DASAR
}

\author{
Candra Puspita Rini \\ Universitas Muhammadiyah Tangerang \\ candrapuspitarini@umt.ac.id
}

\begin{abstract}
This research is aimed to know the effectiveness of SETS approach (Science, Environment, Technology and Society) in influencing students' science process skill. The method used in this research is Quasi Experimental Method. The hypothesis proposed in this study is: "There is a difference in the science process skills between students taught by the SETS (Science, Environment, Technology and Society) approach with students taught by conventional approaches". This research was conducted at SD Negeri Panunggangan 8 Kota Tangerang, Banten. Samples studied were 54 class III students consisting of 27 experimental class students and 27 control class students. The instrument in this study is in the form of multiple choice test. The result of this research concludes that the SETS (Science, Environment, Technology and Society) approach is more effective than the conventional approach to influence the students' science process skills Primary School.
\end{abstract}

Keywords: SETS Approach, Science Process Skills

\begin{abstract}
ABSTRAK
Penelitian ini bertujan untuk mengetahui efektif atau tidaknya pendekatan SETS (Science, Environment, Technology and Society) dalam mempengaruhi keterampilan proses sains siswa. Metode yang digunakan dalam penelitian ini adalah Metode Quasi Eksperimen. Hipotesis yang diajukan dalam penelitian ini adalah : "Terdapat perbedaan keterampilan proses sains antara siswa yang diajarkan dengan pendekatan SETS (Science, Environment, Technology and Society)" dengan siswa yang diajarkan dengan pendekatan konvensional. Penelitian ini dilaksanakan di SD Negeri Panunggangan 8 Kota Tangerang, Provinsi Banten. Sampel yang diteliti sebanyak 54 siswa kelas III yang terdiri dari 27 siswa kelas eksperimen dan 27 siswa kelas kontrol. Instrumen dalam penelitian ini berbentuk tes pilihan ganda. Penelitian menunjukan bahwa hasil tes akhir kelas kontrol dan kelas eksperimen dengan uji-t diperoleh $t_{\text {hitung }}=2,662$ dan $t_{\text {tabel }}=2,000$ hasil penelitian ini menyimpulkan bahwa pendekatan SETS (Science, Environment, Technology and Society) lebih efektif dibandingkan pendekatan konvensional untuk mempengaruhi keterampilan proses sains siswa Sekolah Dasar.
\end{abstract}

Kata Kunci: Pendekatan SETS, Keterampilan Proses Sains 


\section{A. PENDAHULUAN}

Keberhasilan cara guru dalam pembelajaran

khususnya

pembelajaran IPA atau sains dilihat dari penggunaan

pendekatan

pembelajaran.

Pendekatan

pembelajaran yang diberikan pada siswa harus dapat menciptakan suasana yang menyenangkan dan dapat meningkatkan keterampilan proses sains siswa dalam mata pelajaran IPA, salah satunya adalah dengan menggunakan pendekatan SETS (Science, Environment, Technology and Society). Pendekatan SETS merupakan salah satu pendekatan yang berpusat pada siswa sehingga membuat siswa terlatih untuk dapat berpikir secara global, memecahkan masalah dengan menerapkan konsep-konsep yang dimiliki dari berbagai ilmu terkait.

Dengan pendekatan SETS siswa akan mendapatkan berbagai pengalaman dalam kegiatan belajar yang selalu relevan, siswa juga dapat menumbuh kembangkan keterampilan berpikir, keterampilan sains, dan keterampilan sosial seperti kerjasama, toleransi, komunikasi dan respek terhadap gagasan terhadap orang lain.

Berdasarkan observasi yang didapat dari data nilai ulangan harian IPA siswa kelas III SDN Panunggangan 8 Kota Tangerang masih banyak siswa yang mendapat nilai di bawah KKM yang telah ditentukan oleh sekolah yaitu 67 , dari 54 siswa yang terdiri dari 2 kelas yaitu kelas III A 27 siswa dan kelas III B 27 siswa, ada 66\% siswa yang mendapat nilai di bawah KKM, 4\% siswa yang mendapat nilai sama dengan KKM dan ada 30\% siswa yang mendapat nilai diatas KKM.

Hal ini dapat dilihat dengan pendekatan yang sering digunakan guru hanyalah pendekatan konvensional, metode yang terus dilakukan guru di kelas dengan metode ceramah, demontrasi, penugasan, dan resitasi yang berdampak pada kurangnya ketertarikan siswa hingga mengakibatkan kebosanan dan kejenuhan bagi siswa. Selain kurang bervariasinya metode pembelajaran yang diberikan di kelas, peneliti juga 
Pendas : Jurnal Ilmiah Pendidikan Dasar, ISSN Cetak : 2477-2143 ISSN Online : 2548-6950 Volume II Nomor 1, Juni 2017

melihat rendahnya motivasi belajar siswa yang kurang bersemangat dalam belajar IPA. Motivasi merupakan proses internal yang tidak hanya penting untuk membuat siswa dapat belajar dari aktifitas belajar, melainkan penentuan berapa banyak informasi yang mereka dapati hingga dapat menunjukan proses kognitif yang tinggi dan menyerap apa yang telah dipelajari.

Keterampilan proses adalah keterampilan pembelajaran yang bertujuan mengembangkan sejumlah kemampuan fisik dan mental sebagai dasar untuk mengembangkan kemampuan yang lebih tinggi pada diri siswa. Menurut Hosnan (2014) keterampilan proses adalah keterampilan dalam proses belajar mengajar yang menekankan kepada keterampilan memperoleh pengetahuan dan mengkomunikasikan perolehannya itu. Keterampilan proses berarti pula sebagai perlakuan yang diterapkan dalam proses pembelajaran dengan menggunakan daya pikir dan kreasi secara efektif dan efisien guna mencapai tujuan (h.370).

Menurut Funk dkk (1979), keterampilan proses adalah cara mengajarkan

IPA

dengan mengajarkan berbagai keterampilan proses yang biasa digunakan para ilmuan dalam mendapatkan atau memformulasikan hasil IPA (Sapriati, 2008, h. 2.13).

Gagne merumuskan pengertian keterampilan proses dalam bidang ilmu pengetahuan alam (sains): pengetahuan tentang konsep-konsep dan prinsip-prinsip dapat diperoleh siswa bila dia memiliki kemampuankemampuan dasar tertentu, yaitu keterampilan proses sains yang dibutuhkan untuk menggunakan sains. Keterampilan-keterampilan dalam bidang sains itu meliputi: mengamati, menggolongkan, berkomunikasi, mengukur, mengenal dan menggunakan hubungan ruang/waktu, menarik kesimpulan, menyusun definisi operasional, menentukan hipotesis, mengendalikan variabel, menafsirkan data dan bereksperimen (Hamalik, 2013, h. 149-150).

Pembelajaran yang memiliki karakteristik pendukung keterampilan proses sains salahsatunya adalah pendekatan SETS (Science, Environment, Technology and Society). Pendekatan SETS 
Pendas : Jurnal Ilmiah Pendidikan Dasar, ISSN Cetak : 2477-2143 ISSN Online : 2548-6950

merupakan modifikasi dari

pendekatan

STS

(Science,

Technology and Society),

penambahan lingkungan bertujuan

untuk dapat menciptakan proses

pembelajaran IPA yang bermakna

sehingga peserta didik dapat survive atau bertahan di lingkungan. Menurut Binadja (2005), pendekatan SETS merupakan

pendekatan

pembelajaran yang menghubungkan sains dengan unsur-unsur lain, yaitu teknologi, lingkungan maupun masyarakat (Wisudawati, 2014, h. 73). Menurut Sriyanto (2014), pendekatan SETS adalah belajar dan mengajarkan sains dalam konteks pengalaman manusia (h. 252).

Pendekatan SETS cocok untuk mengintegrasikan domain konsep, keterampilan proses, kreativitas, sikap, nilai-nilai, penerapan dan keterkaitan antar bidang studi (kurikulum) dalam pembelajaran dan penilaian pendidikan berdasarkan pengalaman.

Menurut National Science Teachers Asssociation, langkahlangkah dalam melaksanakan pendekatan Sains, Teknologi Lingkungan dan Masyarakat (SETS) antara lain: 1) Tahap Invitasi: pada tahap ini guru mengemukakan issue/masalah aktual yang sedang berkembang di masyarakat sekitar yang dapat diamati/dipahami oleh peserta didik serta dapat merangsang siswa untuk bisa ikut mengatasinya. Selain itu, dapat juga masalah digali dari pendapat atau keinginan siswa dan ada kaitannya dengan konsep sains yang akan dipelajari; 2) Tahap Eksplorasi: pada tahap ini siswa melalui aksi dan reaksinya sendiri berusaha memahami/mempelajari situasi baru atau yang merupakan masalah baginya. Dapat di tempuh dengan cara membaca buku, majalah, koran, mendengarkan berita di radio, melihat TV, diskusi dengan sesama teman atau wawancara dengan masyarakat maupun melakukan observasi langsung di lapangan; 3) Tahap Solusi: pada tahap ini berdasar hasil eksplorasinya siswa menganalisis terjadinya fenomena dan mendiskusikannya bagaimana cara memecahkan masalahnya. Dengan kata lain siswa mengenal dan membangun konsep yang baru sesuai dengan kondisi setempat. Untuk memantapkan konsep yang di peroleh siswa tersebut perlu memberikan umpan 
Pendas : Jurnal Ilmiah Pendidikan Dasar, ISSN Cetak : 2477-2143 ISSN Online : 2548-6950 Volume II Nomor 1, Juni 2017

balik/peneguhan; 4) Tahap Aplikasi: pada tahap ini siswa mendapatkan kesempatan untuk menggunakan konsep yang telah diperoleh. Dalam hal ini siswa mengadakan aksi nyata dalam mengatasi masalah lingkungan yang dimunculkan pada tahap invitasi. Berdasarkan permasalahanpermasalahan diatas, maka penulis tertarik untuk melakukan penelitian dengan judul "Pengaruh Pendekatan SETS (Science, Environment, Technology and Society) Terhadap Keterampilan Proses Sains Siswa Sekolah Dasar".

\section{B. METODE PENELITIAN}

Penelitian ini merupakan penelitian eksperimen dengan penelitian Quasy Experimental Design jenis Control group pre-testpost-tes, dengan adanya kelompok lain yang disebut kelompok perbandingan atau kelompok kontrol ini dapat diketahui dari yang diberi perlakuan dibandingkan dengan yang tidak mendapatkan perlakuan.

Prosedur penelitian dimulai dengan penulis melakukan observasi untuk mengetahui permasalahanpermasalahan yang ada di sekitar SDN Panunggangan 8 Kota
Tangerang, lalu melakukan tes awal (pretes) kepada kelas eksperimen dan kelas kontrol dengan instrumen yang sama, setelah itu emberikan materi pembelajaran yang sama. Pada kelas eksperimen pembelajaran dilakukan dengan menggunakan pendekatan SETS sedangkan pada kelas kontrol dengan menggunakan pendekatan konvensional, langkah terakhir melakukan tes akhir (posttest) kepada kelas eksperimen dan kelas kontrol.

Populasi target yang menjadi objek penelitian ini adalah seluruh siswa SDN Panunggangan 8 Kota Tangerang yang berjumlah 54 siswa. Sampel penelitian ini diambil sesuai pertimbangan peneliti dengan guru kelas, yaitu siswa kelas III yang terdiri dari 2 kelas yaitu III A sebagai kelas kontrol berjumlah 27 siswa dan III B sebagai kelas eksperimen berjumlah 27 siswa. Instrumen penelitian yang digunakan dalam penelitian ini berupa tes dan lembar observasi. Instrumen ini sebelumnya diujicobakan terlebh dahulu sebelum diberikan kepada subyek penelitian. Teknik analisis data dilakukan ketika seluruh data yang diperlukan telah terkumpul. 
Pendas : Jurnal Ilmiah Pendidikan Dasar, ISSN Cetak : 2477-2143 ISSN Online : 2548-6950

Data hasil penelitian berupa tes akan dianalisis secara deskriptif dan inferesnsial, dan hasil observasi pelaksanaan pembelajaran dianalisis secara deskriptif untuk memberikan gambaran pelaksanaan pembelajaran yang menggunakan pendekatan SETS dan keterampilan proses sains siswa selama proses pembelajaran.

\section{HASIL DAN PEMBAHASAN}

Proses pelaksanaan penelitian dengan menggunakan pendekatan SETS dimulai dari tahap invitasi yaitu tahap yang memunculkan permasalahan actual dari fenomenafenomena yang sering dijumpai siswa dalam kehidupan sehari-hari. Tujuannya adalah siswa dapat berpikir secara kritis dapat merangsang siswa untuk bisa ikut mengatasi masalah tersebut. Selain itu siswa dituntut untuk berpikir tentang konsep IPA yang terkandung dalam fenomena tersebut. Tahap selanjutnya adalah tahap eksplorasi dan solusi, pada tahap ini guru mengorganisasi siswa untuk belajar secara berkelompok, dimana dalam satu kelompok terdiri dari lima siswa; membagikan LKS; serta menjelaskan alat dan bahan yang diperlukan untuk proses eksperimen. Setelah siswa duduk dalam kelompoknya, kemudian dilanjutkan dengan tahap penyelidikan dimana siswa melakukan eksperimen sesuai pedoman LKS dan mendiskusikan pertanyaan atau permasalahan yang ada di LKS untuk dicari penyelesaiannya atau solusinya berdasarkan pengamatan dari fenomena yang muncul melalui kegiatan eksperimen. Setelah diskusi kelompok selesai, dilanjutkan dengan tahap penyajian hasil penyelidikan dimana siswa beserta kelompoknya mempresentasikan hasil diskusi di depan kelas. Dengan demikian, keterampilan melaporkan hasil eksperimen merupakan salah satu keterampilan yang penting, karena selain mampu melakukan kegiatan eksperimen dan mengumpulkan data, siswa juga harus mampu melaporkan hasilnya.

Tahap terakhir adalah tahap aplikasi dimana siswa menjelaskan fenomena yang terjadi pada kegiatan pengamatan siswa pada fenomena berdasarkan kegiatan eksperimen yang telah mereka lakukan. Pada tahap ini juga, siswa harus dapat 
Pendas : Jurnal Ilmiah Pendidikan Dasar, ISSN Cetak : 2477-2143 ISSN Online : 2548-6950 Volume II Nomor 1, Juni 2017

membuat kesimpulan mengenai materi yang telah dipelajari dan dapat mengadakan aksi nyata dalam mengatasi masalah lingkungan yang dimunculkan pada tahap invitasi. Pembelajaran melalui kegiatan pengamatan langsung seperti ini dapat menjadikan belajar lebih bermakna serta berfungsi untuk memperkuat pemahaman siswa terhadap fenomena yang ditampilkan malalui demonstrasi maupun eksperimen. Dengan demikian, belajar tidak hanya melalui penyampaian informasi dan produk sains tetapi diperlukan juga adanya proses siswa untuk mengalami secara langsung sehingga siswa membangun pengetahuan baru dari pengetahuan yang mereka miliki sebelumnya. Pendekatan SETS mempunyai peran yang sangat penting dan berkesempatan bagi siswa untuk mengembangkan kemampuan, mengamati dengan teliti, penuh perhatian, partisipasi dan penuh tanggungjawab terhadap suatu proses yang sedang digunakan dalam pembelajaran IPA, serta dapat menarik/mengambil kesimpulankesimpulan yang bermanfaat sesuai dengan harapan.
Kelas eksperimen pada penelitian ini menggunakan pendekatan SETS melalui metode demonstrasi dan eksperimen sedangkan kelas kontrol menggunakan pendekatan konvensional melalui metode ceramah dan demonstrasi. Yang membedakan kedua kelas ini adalah metode dan cara penyajian permasalahan dari fenomena yang akan dipelajari. Untuk kelas eksperimen penyajian fenomena melalui kegiatan demonstrasi sedangkan untuk kelas kontrol secara lisan tanpa demonstrasi. Secara keseluruhan, baik kelas eksperimen maupun kelas kontrol sama-sama mengalami peningkatan. Berdasarkan hasil analisis dan hasil perhitungan dengan rumus uji-t menunjukkan bahwa nilai yaitu 2,662 $>$ 2,000. Oleh karena itu dapat disimpulkan bahwa pendekatan SETS melalui metode demonstrasi dan eksperimen berpengaruh terhadap keterampilan proses sains siswa kelas III SDN Panunggangan 8 Kota Tangerang. Jika dilihat dari ratarata kelas, siswa yang mendapatkan pembelajaran menggunakan pendekatan SETS diperoleh rata-rata 
Pendas : Jurnal Ilmiah Pendidikan Dasar, ISSN Cetak : 2477-2143 ISSN Online : 2548-6950 Volume II Nomor 1, Juni 2017

kelas yaitu 18,50 lebih baik daripada siswa yang mendapat pembelajaran dengan metode konvensional, diperoleh rata-rata kelasnya 16,06. Hal ini menunjukkan bahwa pembelajaran menggunakan pendekatan SETS lebih efektif dibandingan pendekatan konvensional dalam mempengaruhi keterampilan proses sains siswa kelas III SDN Panunggangan 8 Kota Tangerang.

Tabel 1. Hasil Perhitungan Uji-t Data Postest Kelas Kontrol dan Kelas Eksperimen

\begin{tabular}{|l|c|c|}
\hline \multirow{2}{*}{ Data } & \multicolumn{2}{c|}{ Postes } \\
\cline { 2 - 3 } & Kontrol & Eksperimen \\
\hline$x$ & 16,06 & 18,50 \\
\hline$S^{2}$ & 10,87 & 11,81 \\
\hline$t_{\text {hitung }}$ & \multicolumn{2}{|c|}{2,662} \\
\hline$t_{\text {tabel }}$ & \multicolumn{2}{c|}{2,000} \\
\hline Kesimpulan & \multicolumn{2}{|c|}{ Ho ditolak } \\
\hline
\end{tabular}

\section{KESIMPULAN}

Kesimpulan dari penelitian ini bahwa ternyata penggunaan pendekatan SETS berpengaruh untuk meningkatkan keterampilan proses sains siswa Sekolah Dasar. Hal ini terbukti dengan hasil perhitungan menggunakan uji-t,dengan nilai $t_{\text {hitung }}$ $=2,662$ sedangkan untuk $t_{\text {tabel }}=$ 2,000. Rata-rata kelas, siswa yang mendapatkan

pembelajaran menggunakan pendekatan SETS diperoleh rata-rata kelas yaitu 18,50 lebih baik daripada siswa yang mendapat pembelajaran dengan metode konvensional, diperoleh ratarata kelasnya 16,06. Hal ini menunjukkan bahwa pembelajaran menggunakan pendekatan SETS lebih efektif dibandingan pendekatan konvensional dalam mempengaruhi keterampilan proses sains siswa kelas III SDN Panunggangan 8 Kota Tangerang. Saran yang dapat penulis kemukakan adalah: 1) Ketika pembelajaran berlangsung diharapkan guru mempersiapkan segala sesuatu yang dibutuhkan secara maksimal dan lebih bisa mengontrol serta membimbing siswa dalam melaksanakan kegiatan pembelajaran sehingga dapat mencapai skor keterampilan proses sains siswa yang maksimal. 2) Pihak sekolah perlu mengambil kebijakankebijakan yang mendukung pelaksanaan pembelajaran yang menerapkan pendekatan SETS agar guru dapat mengembangkan pembelajaran dengan pendekatan SETS. 
DAFTAR PUSTAKA

A. M, Sardiman, Aryani, (2011). Interaksi \& Motivasi Belajar Mengajar. Jakarta: PT. Raja Grafindo Persada.

Arikunto, Suharsimi. (2012). DasarDasar Evaluasi Pendidikan. Jakarta: Bumi Aksara

Hamalik, Oemar. (2013). Kurikulum dan Pembelajaran. Jakarta: Bumi Aksara

Hosnan, M. (2014). Pendekatan Saintifik dan Kontekstual dalam Pembelajaran Abad 21 Kunci sukses Implementasi Kurikulum 2013. Bogor: Penerbit Ghalia Indonesia.

Riadi, Edi. (2014). Metode Statistika Parametrik dan Nonparametrik Untuk Penelitian IImu-IImu Sosial dan Pendidikan. Tangerang: PT Pustaka Mandiri.

Rustaman, Nuryani. (2013). Materi dan Pembelajaran IPA SD. Jakarta: Universitas Terbuka.

Samatowa, Usman. (2010). Pembelajaran IPA di Sekolah Dasar. Jakarta: PT. Indeks.

Sanjaya, Wina. (2010). Strategi Pembelajaran Berorientasi Standar Proses Pendidikan. Jakarta: Kencana Prenada Media Group.

Sapriati, Amalia. (2014). Pembelajaran IPA di SD. Jakarta: Universitas Terbuka.

Sriyanto (2014). Seminar Nasional Menjadi Guru Kreatif, Mengembangkan Kemampuan
Konseptual, dan Keterampilan Pedagogis dalam Pembelajaran. Yogyakarta: Program Studi Pendidikan Guru sekolah Dasar (PGSD) S1 FKIP UMP dan Amara Books.

Sugiyono. (2012). Statistika Untuk Penelitian. Bandung: Alfabeta.

Susanto, Ahmad, (2013). Teori Belajar dan Pembelajaran di Sekolah Dasar. Jakarta: Kencana Prenada Media Group.

Trianto. (2010). Model Pembelajaran Terpadu, Konsep, Strategi dan Implementasinya dalam Kurikulum Tingkat Satuan Pendidikan (KTSP). Jakarta: Bumi Aksara

W, Anitah, Sri. (2008). Strategi Pembelajaran Matematika. Jakarta: Universitas Terbuka.

Wisudawati, Widi, Asih, (2014). Metodologi Pembelajaran IPA. Jakarta: Bumi Aksara. 